\title{
Determinants of Trade Misinvoicing
}

\author{
Ila Patnaik, Abhijit Sen Gupta, Ajay Shah
}

Working Paper No. 2010-75

October 2010

\author{
National Institute of Public Finance and \\ Policy \\ New Delhi \\ http://www.nipfp.org.in
}




\title{
Determinants of Trade Misinvoicing
}

\author{
Ila Patnaik* \\ Abhijit Sen Gupta** \\ Ajay Shah
}

\begin{abstract}
Traditional explanations for trade misinvoicing -- high custom duties and weak domestic economies - are less persuasive in a world of high growth emerging markets who have low trade barriers. We construct a 35country data set over a 26 year span, covering both industrialised and developing countries, to study the phenomena of export and import misinvoicing. Capital account openness, differentials in interest rates, political stability, corruption, indebtedness and the exchange rate regime are identified as factors related to misinvoicing. Trade misinvoicing should be seen as one element of de facto capital account openness.
\end{abstract}

Keywords: Trade Misinvoicing, Capital Account Openness, Political Stability, Custom Duties.

* Ila Patnaik, Professor, National Institute of Public Finance and Policy, 18/2 Satsang Vihar Marg, New Delhi 110067 INDIA

Tel: +91-11-26963421, E-mail: ilapatnaik@gmail.com

${ }^{* *}$ Abhijit Sen Gupta, Associate Professor, Jawaharlal Nehru University, New Delhi 110067 INDIA

Tel: +91-11-26738739, E-mail: abhijitsengupta@gmail.com

${ }^{* * *}$ Ajay Shah, Professor, National Institute of Public Finance and Policy, 18/2

Satsang Vihar Marg, New Delhi 110067 INDIA

Tel: +91-11-26961829, Email: ajayshah@mayin.org

This study has been done under the NIPFP-DEA Research Program. The authors are grateful to Sandhya Krishnan for excellent research assistance. 


\section{Introduction}

The magnitude of trade misinvoicing is conventionally estimated by juxtaposing trade data from the importing and the exporting country. A firm interested in moving capital out of a country would underinvoice its exports, thus bringing reduced foreign exchange into the country. Similarly, overinvoicing of imports would allow the domestic importer to gain access to greater foreign exchange than required. Both these mechanisms leave domestic firms in control of hard currency assets overseas. Underinvoicing of imports, on the other hand, can result from an attempt to evade taxes on imports including customs duties and the VAT on imports.

The overall misinvoicing of imports that is computed using macroeconomic data reflects a certain cancelling out between certain firms who are engaged in underinvoicing of imports and other firms who are engaged in overinvoicing of imports. Similar considerations apply with misinvoicing of exports. To the extent that firms have heterogeneous goals, the measured misinvoicing is likely to understate the true scale of gross capital flows being achieved through misinvoicing in an economy.

The traditional literature focussed on two broad motivations for misinvoicing. First, it emphasised high customs duties (de Boyrie et. al., 2007; Boyce and Ndikumana, 2001; Beja et. al., 2005): When firms pay high rates of customs duties or VAT on imports, they have an incentive to understate the true value of imports. Second, misinvoicing was viewed as a method for achieving capital flight, which was (in turn) motivated by fears of expropriation in an interplay between unsound economic policy and political instability (Schulze, 1994).

A critical factor influencing trade misinvoicing that has been identified in the literature is the extent of exchange rate overvaluation. An overvalued exchange rate as well as high inflation rate raise expectations of depreciation in the near future and stimulate capital flight. Research on the determinants of the large outflows of capital from Latin American countries in 1980s and Asian economies in late 1990s has identified explanatory variables such as macroeconomic instability, large budget deficits, low growth rates and the spread between foreign and domestic interest rates (Cuddington, 1987; Muscatelli and Hallett, 1992; Pastor, 1990; Cuddington, 1986; Vos, 1992; Boyce, 2002; Ketkar and Ketkar, 1989). These factors, as well as others such as corruption, political freedom and accountability were significant in explaining capital flight from sub Saharan Africa (Ngeno, 2000; Murinde et al. 1996; Hermes and Lensink, 1992; Ndikumana and Boyce, 2002).

By the logic of this traditional literature, when countries like India and China achieved high GDP growth and cut customs duties, the motivation for misinvoicing should have subsided. In this paper, we find that by and large, such a decline in misinvoicing is not visible. Hence, there is a need to review the evidence for misinvoicing, including countries with stable political systems and robust economic growth, in a period with low trade barriers, in a quest for alternative explanations. That analysis is undertaken in this paper.

The recent literature has identified interesting links between trade and capital 
account openness. Aizenman (2003) and Aizenman and Noy (2004) describe the twoway links between trade liberalisation and capital account liberalisation. Aizenman (2004) in countries that have capital account restrictions, greater trade integration creates greater opportunities to shift capital through trade misinvoicing. Conversely, Wei and Zhang (2007) show that capital controls impede trade. These factors may generate a causal relationship between greater trade openness and capital account liberalisation. Aizenman and Noy (2008) find that a one standard deviation increase in trade openness is associated with $9.5 \%$ increase in financial openness.

The contribution of this paper lies in a fresh examination of the evidence on misinvoicing with a broader dataset than has been generally used. Most of the existing literature has focused on countries from Africa and Latin America. We extend the data set by looking at a number of countries from South and East Asia, as well as Eastern Europe. We include a number of industrialized countries in our data set, which have not featured in most of the existing literature on capital flight. We examine variables such as custom duties, tax rates, political stability, economic stability, law and order, etc. as potential determinants of trade misinvoicing. We also analyse misinvoicing from the viewpoint of de facto openness of the current and capital accounts. We report evidence about the extent to which misinvoicing is motivated by the desire to avoid capital controls, and the extent to which it constitutes an important element of de facto convertibility.

Our results suggest that trade misinvoicing should be seen as one element of de facto openness on the capital account. Economic agents who desire capital movements for traditional reasons such as financial portfolio diversification, bets on exchange rate movements, are likely to achieve these movements through trade misinvoicing. To the extent that misinvoicing is feasible, countries do not have a choice about embarking on high capital account openness once they have adopted high current account openness. Thus, we link the older literature on trade misinvoicing with the considerable literature from the following decades on capital account liberalisation by emerging markets.

The remainder of this paper is organised as follows. In Section 2, we describe our method of measuring misinvoicing and the resulting dataset. Simple graphical analysis is shown in Section 3 and Section 4 examines the data using regression models. Section 5 presents the key results of both the graphical and regression analyses, while Section 6 concludes and proposes avenues for further research.

\section{Measuring Misinvoicing: The Methodology}

Trade misinvoicing can take place either through export and import overinvoicing or underinvoicing. Ideally, the observed exports from country A to country $B$ (including the cost of insurance and shipping (CIF)) should match the observed imports of Country B from Country A. If the exports from Country A to B (CIF) are less than the claimed imports of Country $B$ from $A$, then the difference can be attributed to export underinvoicing by Country $\mathrm{A}$, or import overinvoicing by Country $\mathrm{B}$.

Discrepancies between data from an importer and the data from the exporter could be attributed to mistakes in recordkeeping. However, if the errors in record 
keeping take place randomly and have mean zero, then averaging these across millions of containers should yield very small discrepancies at an aggregate level. When industrial countries trade with industrial countries, it is likely that record-keeping on both sides is done using high quality computer systems. Hence, random errors in measurement are likely to be smaller.

The data on misinvoicing used in earlier studies was usually limited to a few countries or a continent. We construct a dataset for 53 major countries' (18 industrialized countries and 35 developing countries) over a span of 26 years (1980-2005) and evaluate the extent of trade misinvoicing in each country in the dataset against industrialized countries. By looking at both industrialized and developing countries we are able to identify the varying factors affecting capital mobility through trade misinvoicing.

We measure trade misinvoicing by using data from IMF's Data on Trade Statistics (DOTS). The DOTS database reports bilateral merchandise exports and imports data between trading partners. Misinvoicing is calculated by looking at the bilateral export and import data between individual countries and their trading partner. The aggregate GDP of countries in the data set works out to $95 \%$ of global GDP in exchange rate terms and $91 \%$ of GDP in terms of purchasing power parity. We focus on the misinvoicing implicit in trade data of a given country against industrial countries only. To the extent that industrial country trade statistics are more accurately captured, this is expected to be less noisy. This biases the interpretation of our overall results: the true scale of capital flows through misinvoicing against the world would be bigger when compared with the values seen here.

We measure misinvoicing in country $i$ vis-á-vis its industrialized trading partners as follows:

$$
\begin{aligned}
& X_{\text {mis }}{ }_{i t}=M_{j t}-\left(X_{i t}{ }^{*} \text { cif }\right) \\
& \text { Mmis }_{\text {it }}=M_{i t}-\left(X_{j t}{ }^{*} \text { cif }\right)
\end{aligned}
$$

Equation (I) measures export misinvoicing by country $\mathrm{i}$ in year $\mathrm{t}$, where Mjt refers to imports of industrialized country $j$ from country $i$ in year $t$ as reported by country $j$. Xit refers to exports of country $i$ to industrialized country $j$ in year $t$ as reported by country i. cif refers to the ratio of cif to fob. A positive value of Xmisit would indicate export underinvoicing by country $i$ in year $t$. On similar lines, a positive value of Mmisit in equation (II) would reflect import overinvoicing by country $i$ in year $t$. The misinvoicing figures for country $\mathrm{i}$ are arrived at by applying equations I and II to all the industrialized trading partners of country.i

\section{Graphical Analysis}

We now present a graphical analysis of misinvoicing in this dataset, from two perspectives. In section 3.1, we compare the extent of misinvoicing in developing and 
industrialized countries over the period 1980-2005. In sections 3.2 and 3.3 , we take a look at some of the observed relationships between both export and import misinvoicing and few of the key macroeconomic and institutional variables that are found to impact trade misinvoicing in the existing literature ${ }^{\mathrm{ii}}$.

\subsection{Misinvoicing in Industrialized v/s Developing Countries}

In the modern period, where industrial countries have near-zero customs duties and near-zero barriers to capital mobility, we would expect to get small values for misinvoicing for trade between industrial countries and industrial countries. If we maintain a null hypothesis that zero trade misinvoicing is indeed present, then the distribution of estimated misinvoicing that is obtained between industrial countries and industrial countries would reflect the sampling noise present in this estimation. 
Figure 1: Kernel Density Plots of Invoicing Measure

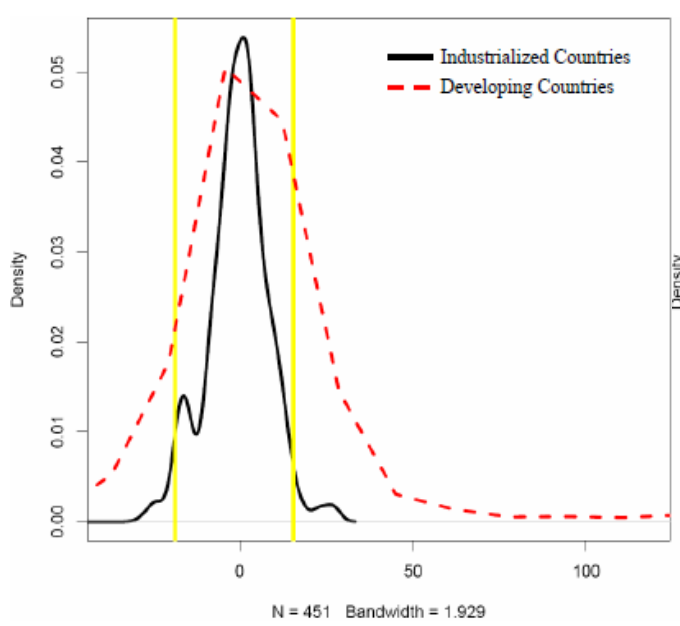

(a) Export Misinvoicing vis-à-vis ICs

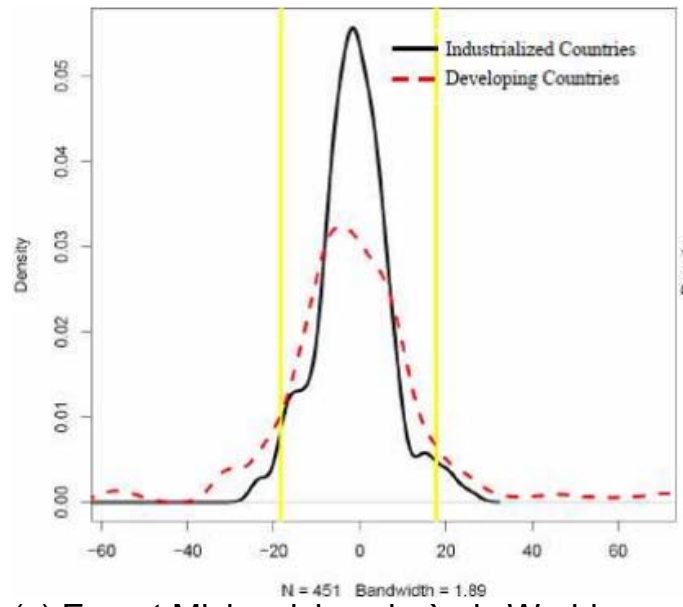

(c) Export Misinvoicing vis-à-vis World

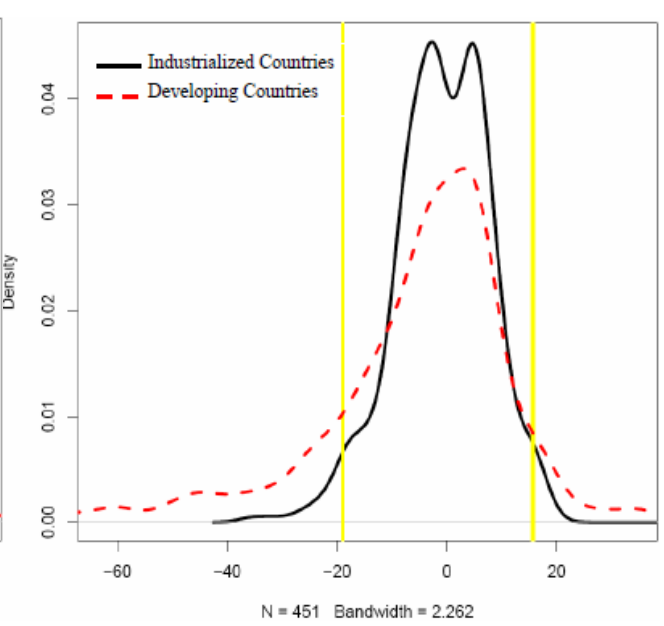

(b) Import Misinvoicing vis-à-vis ICs

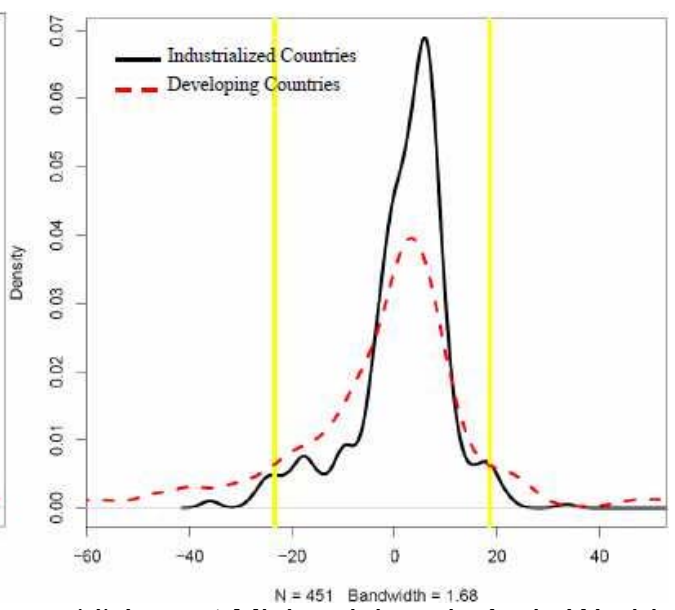

(d) Import Misinvoicing vis-à-vis World

Figure 1 describes the kernel density plots of export and import misinvoicing measures. Figures (a) and (b) show misinvoicing vis-a-vis industrial countries, while (c) and (d) show misinvoicing vis-a-vis the rest of the world. The solid black line represents the density plot for industrialized countries, while the dashed line refers to the developing countries. The vertical lines exhibit the $2.5 \%$ and $97.5 \%$ boundaries for the industrialized countries.

Comparing the density plots of the developing countries with the industrialized countries, it is evident that a sizeable proportion of observations for developing countries lie outside the $95 \%$ interval for the industrialized countries. This pattern is uniform across export and import misinvoicing vis-á-vis industrialized countries as well 
as the world. Thus, the extent of misinvoicing seems to be significantly higher among developing countries compared to industrialized countries. Even if we maintain a null hypothesis that no misinvoicing takes place between industrial and industrial trade partners, the evidence for developing countries clearly rejects the null hypothesis that misinvoicing is absent when it comes to developing countries.

Figure 2: Export Misinvoicing as a percentage of Exports (1980-2005)

(a) USA

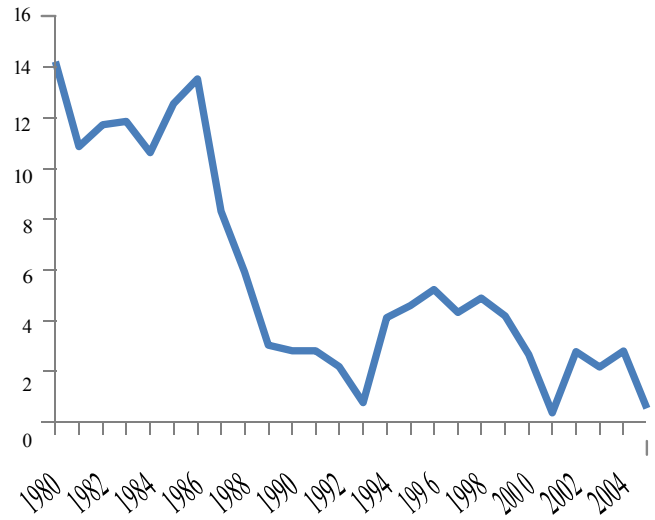

(c )Italy

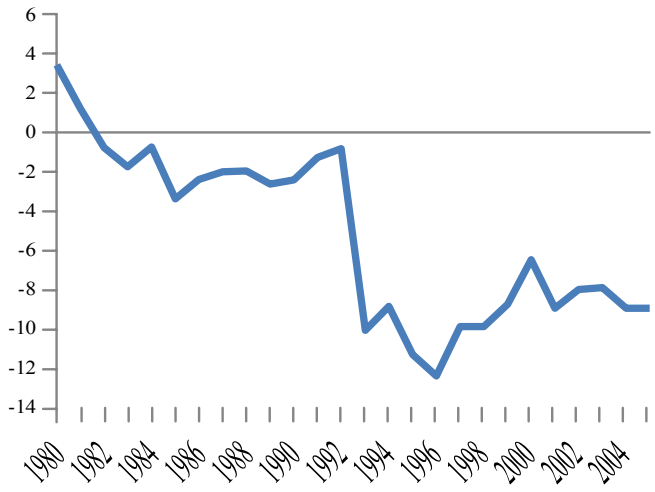

(e) Brazil

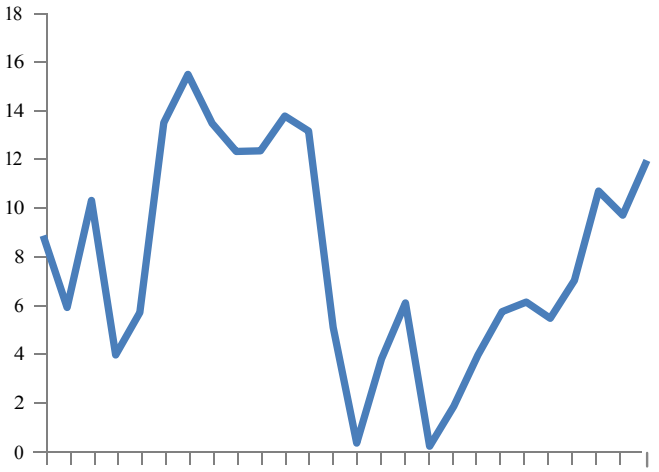

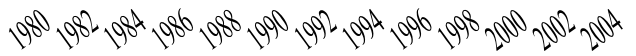

(b) France

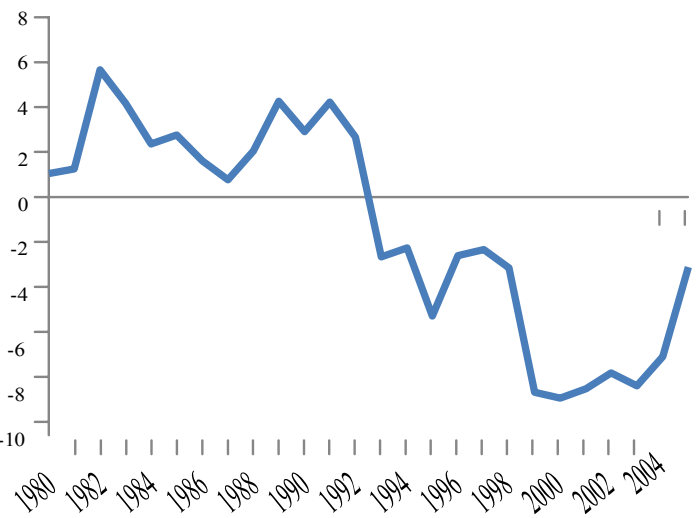

(d) India

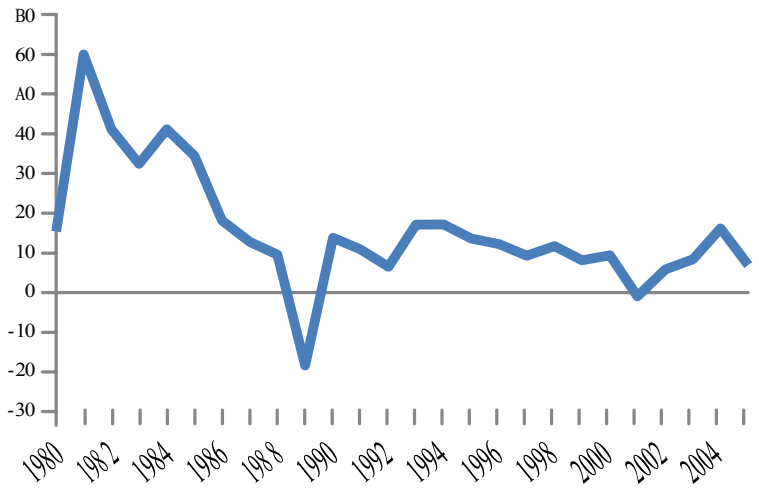

(f) Indonesia

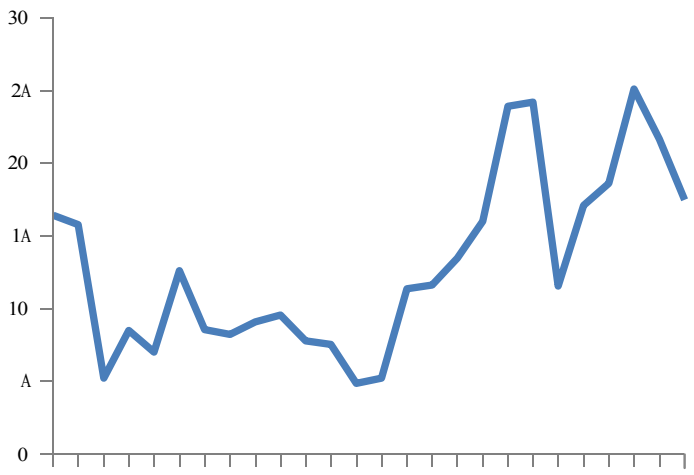

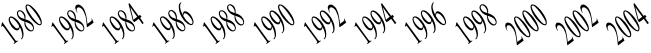


The extent of misinvoicing has steadily decreased in industrialized countries over the last 25 years. Figure 2 traces the path of export misinvoicing across six countries - three industrialized countries and three emerging markets. Around 1980, the United States was experiencing export underinvoicing worth of more than $14 \%$ of its exports. However, over the next 25 years this has steadily declined to less than one percent in 2005. Similarly, Italy and France, which experienced capital flight through export underinvoicing in early 1980s saw a reversal in its trend since 1992 as capital started flowing into these economies through trade misinvoicing. A similar pattern of decline in capital flight through export misinvoicing was also witnessed in other industrialized countries like Spain, Netherlands, Finland and Canada. The experience with industrial country misinvoicing is broadly consistent with the dates of capital account liberalisation by industrial countries; this suggests that once capital account restrictions are eliminated, the motivation for trade misinvoicing subsides.

In contrast, the decline in capital flight through export underinvoicing in developing countries was nowhere as dramatic as in the industrialized countries. In fact, the evidence from developing countries is quite mixed. While some countries like India and Philippines witnessed a decline in export misinvoicing between 1980 and 2005, others like Brazil, Chile and Colombia did not experience a significant decline. On the other hand, several countries like Indonesia, Thailand and Malaysia saw an increase in export misinvoicing. The broad empirical facts for developing countries are consistent with the prevalence of restrictions against capital mobility.

Focussing on import underinvoicing also yields a simailar picture where the developed countries witnessed a strong decline in capital flight through import underinvoicing during the period 1980-2005, whereas the developing countries provide a mixed response. 


\subsection{Export Misinvoicing}

Figure 3: Relationship between Export Underinvoicing and Key Variables

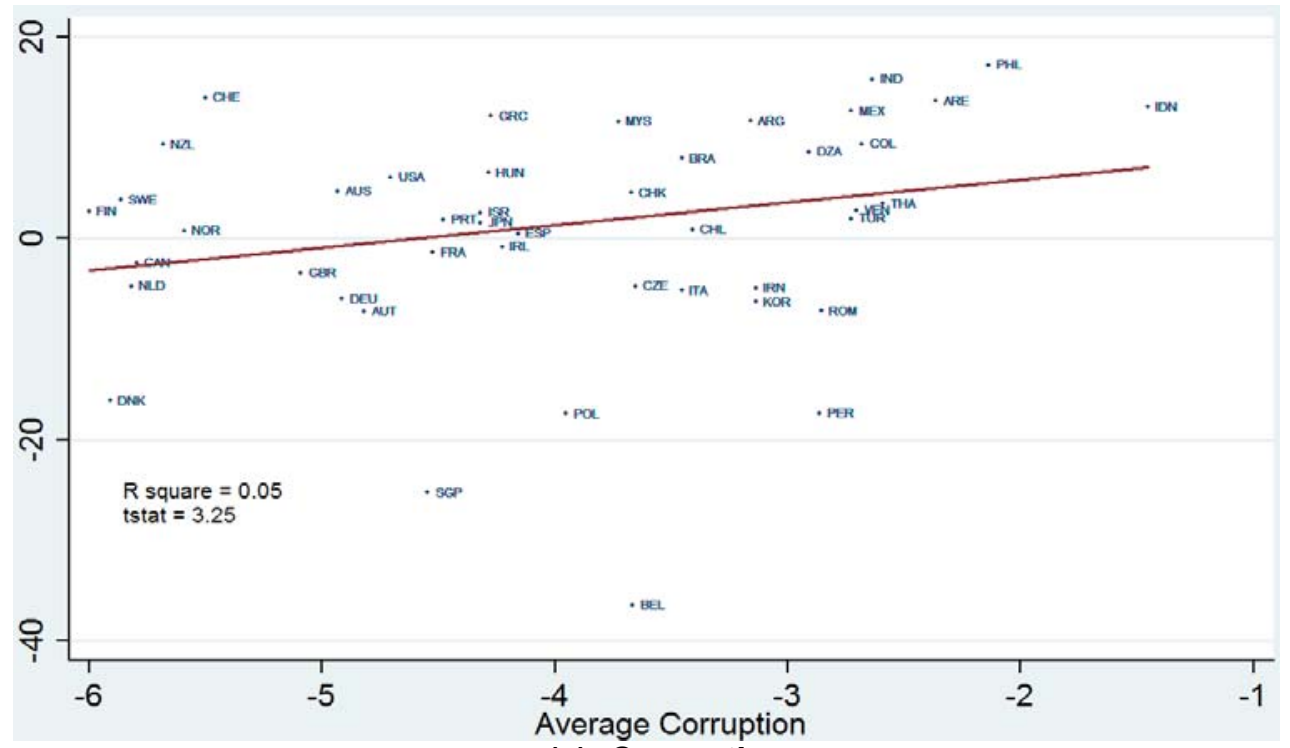

(a) Corruption

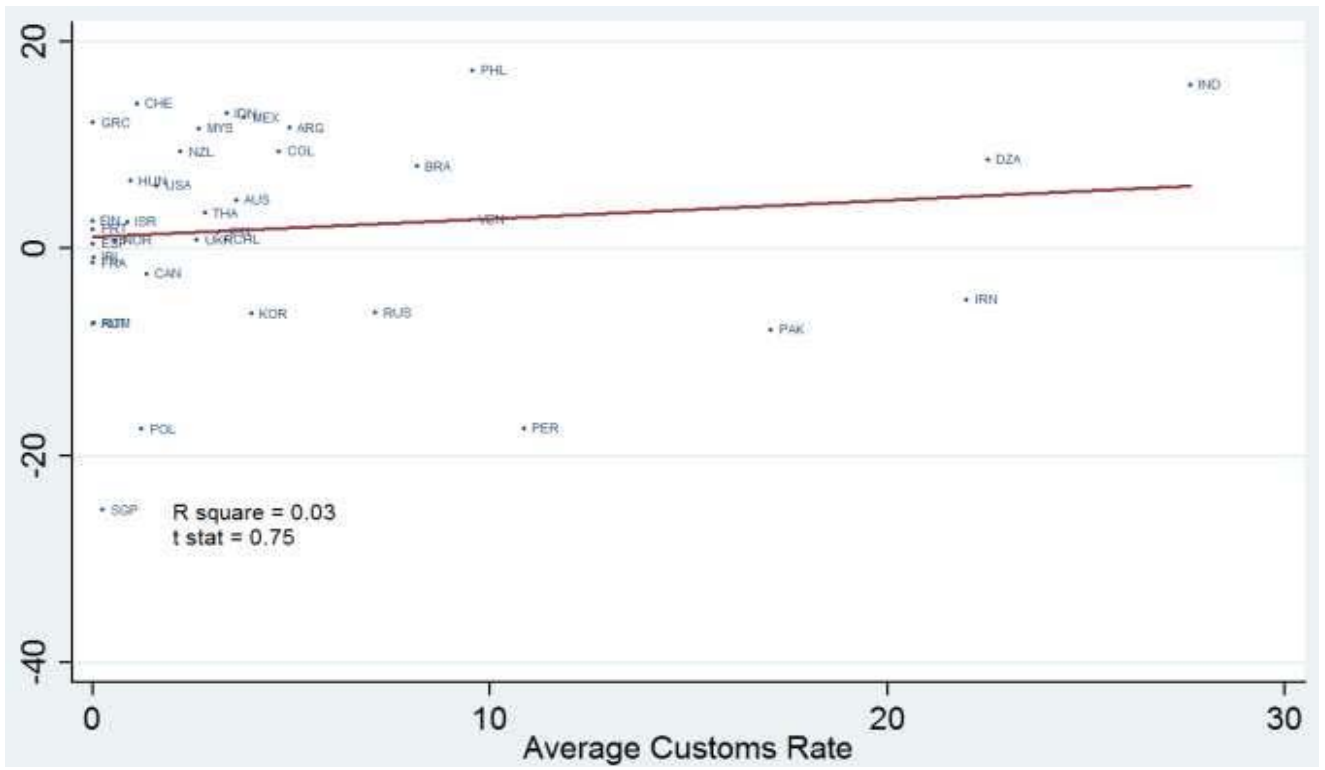

(b) Custom Duties 


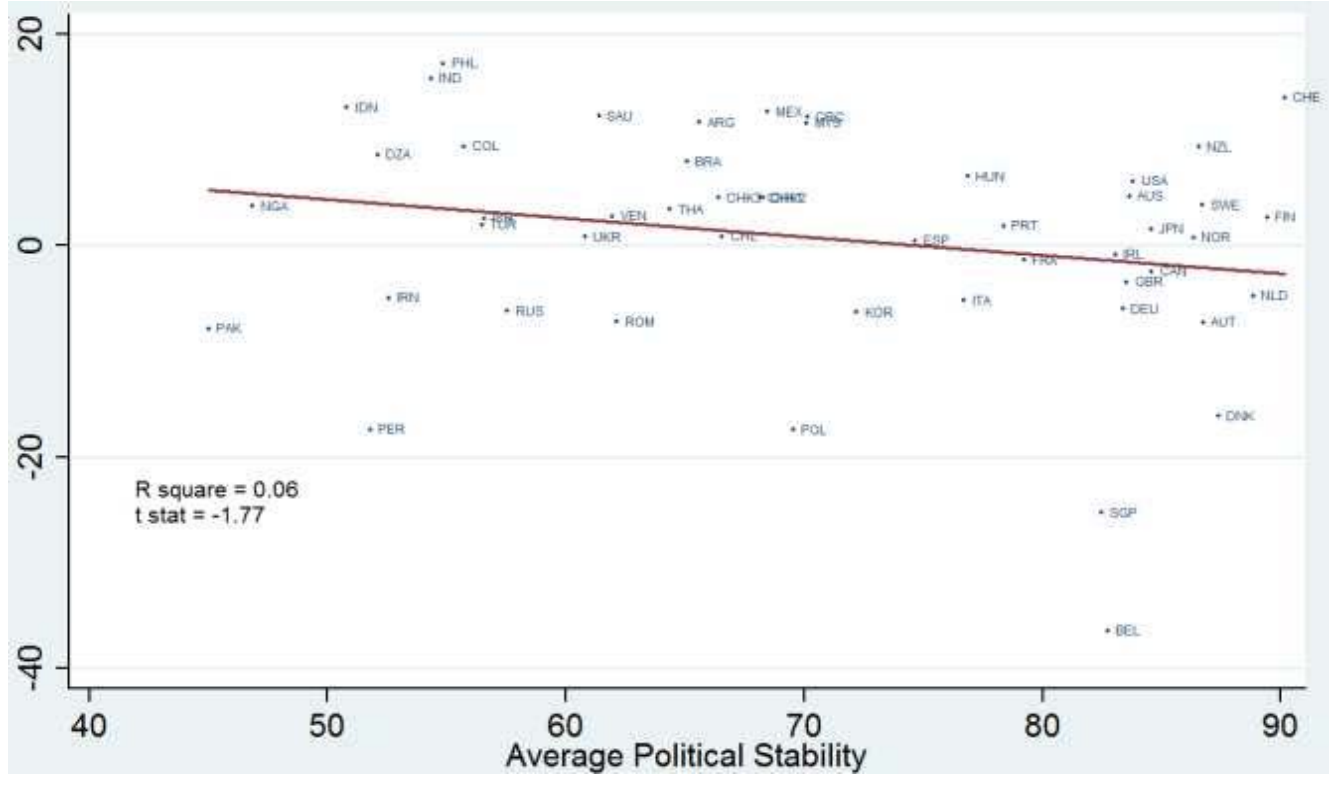

(c) Political Stability

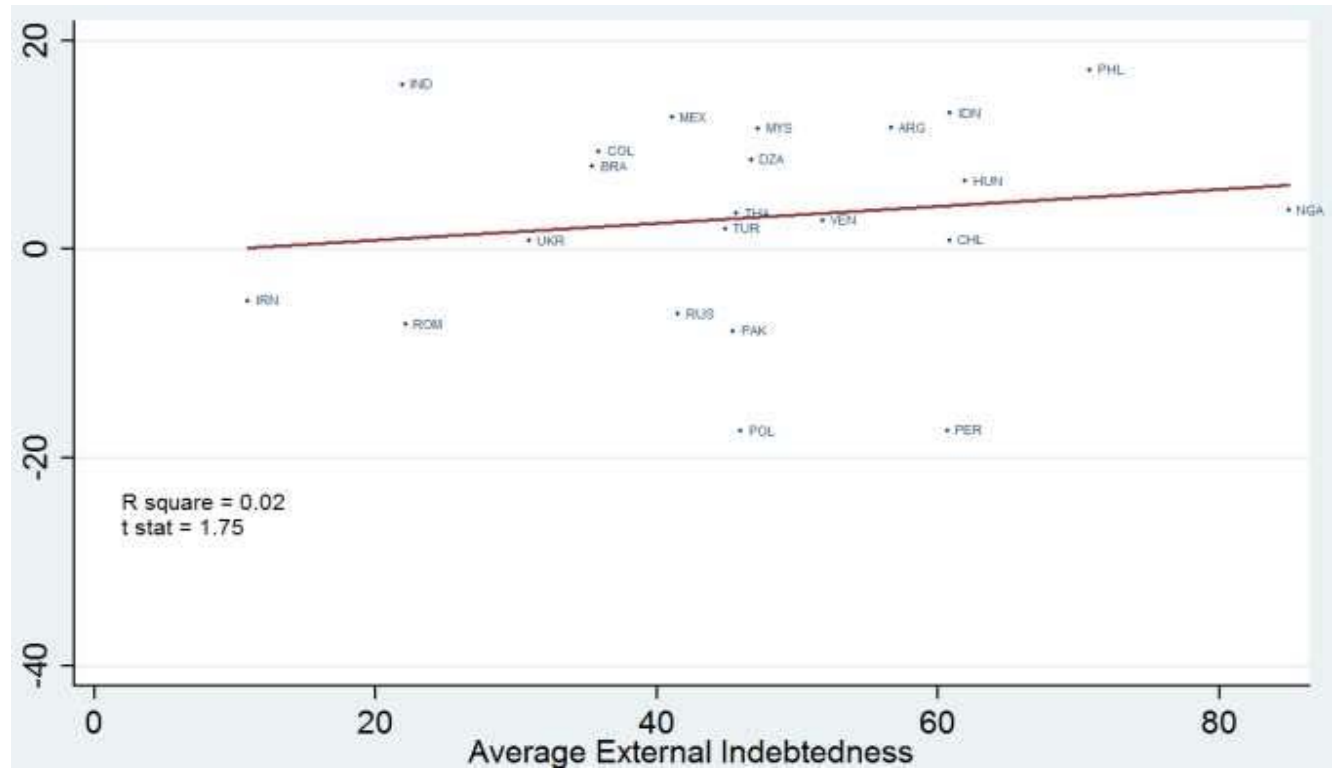

(d) Indebtedness 


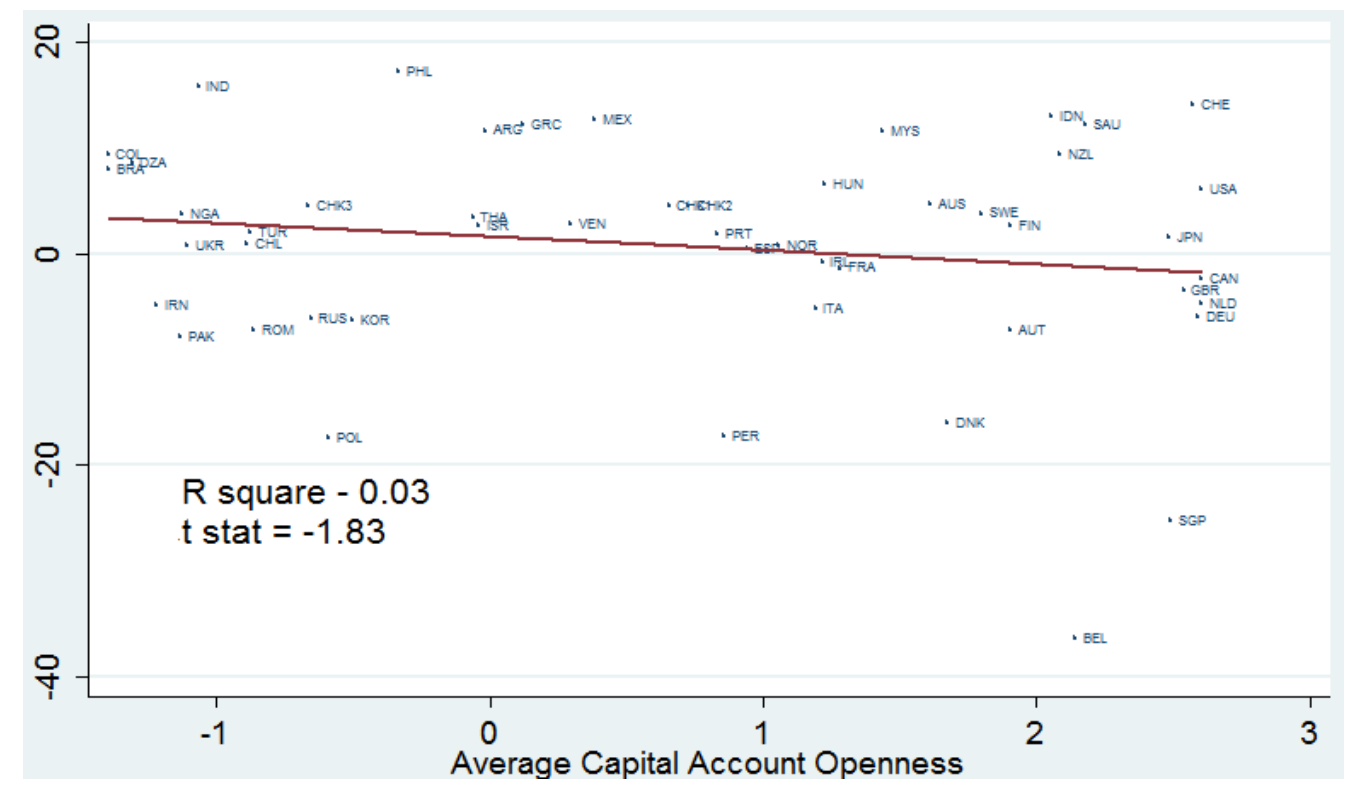

(e) Capital Account Openness

Figure 3 measures the extent of export underinvoicing on the vertical axis. A higher number indicates greater capital flight through export underinvoicing with the industrialized countries, that is, the exporting country is claiming that it has exported less than what is being reported as having been imported by importing countries.

We find that higher capital flight tends to be associated with more corrupt countries (Figure 3a). For example, countries like Nigeria, Pakistan and Ukraine that rank as most corrupt countries according to our measure are also the countries that witness maximum capital flight.

Countries that have high custom duties have also experienced more capital flight through underinvoicing of exports (Figure $3 \mathrm{~b}$ ). A prime example in this case is India, where custom duties averaged in excess of $27 \%$ during the period under study and capital flight through export underinvoicing amounted to $15 \%$ of the country's total exports. On the other hand, industrialized countries like Australia, Ireland, Spain, etc., which virtually abolished custom duties during the same period, witnessed very limited capital flight from underinvoicing of exports.

Greater political stability tends to be related with lower misinvoicing of exports. Quan Vu Le and Paul Zak (2001) have found for a sample of 47 developing countries that unconstitutional government change, internal uprisings and the variance of policy implementation exert a positive influence on capital flight. Boyce and Ndikumana (2003), in their study on capital flight from Sub-Saharan African countries find the estimated coefficients of political and governance indicators to have the expected signs. The relationship, however, is not statistically significant. 
There is a positive relationship between external indebtedness and misinvoicing (Figure 3d). The evidence from African countries has shown that typically the government engages in foreign borrowing from donor countries and multilateral agencies, while the private sector shifts funds abroad. Moreover, the drain of foreign exchange resources through capital flight creates further demand for external borrowing. Khan and Ul-Haque (1985) point out that in developing countries the perceived risk of investment is higher than in industrialized countries. Residents of developing countries can expect risk-free compensation for the additional risk on their investment at home. Khan and UI-Haque (1985) call this expropriation risk, implying that residents of these countries can have their assets expropriated by the government through outright nationalization, taxes, or exchange controls, whereas, the risk on similar assets held abroad is negligible. Consequently, an exogenous or policy-induced shock that raises the perceived level of risk could result in capital flight.

Capital account liberalization mitigates capital flight by reducing market distortions. Also, with an open capital account capital flight is likely to take place through the capital account. Consequently, a country with an open capital account, even if it witnesses capital flight, is not likely to see it happen through trade misinvoicing. However, if financial markets are repressed then capital account liberalization can have adverse consequences. With domestic interest rates being significantly lower than foreign interest rates, domestic agents will have the incentive to hold their wealth in foreign assets. Moreover, the liberalization of capital account operations if the exchange rate is overvalued, can lead to higher capital flight. In our sample of countries, we find that greater capital account openness is associated with lower export misinvoicing.

\subsection{Import Misinvoicing}

Next, we consider the case where capital flight takes place through overinvoicing of imports, that is, the importing country has claimed it has imported more than what the exporting countries have exported. We find that corruption and capital account openness exert limited influence on capital flight through import overinvoicing. Higher custom duties are associated with lower overinvoicing of imports. Typically, in countries with high custom duties, importers will have the incentive to declare a lower worth of their goods to avoid paying these duties. 
Figure 4: Relationship between Import Overinvoicing and Key Variables

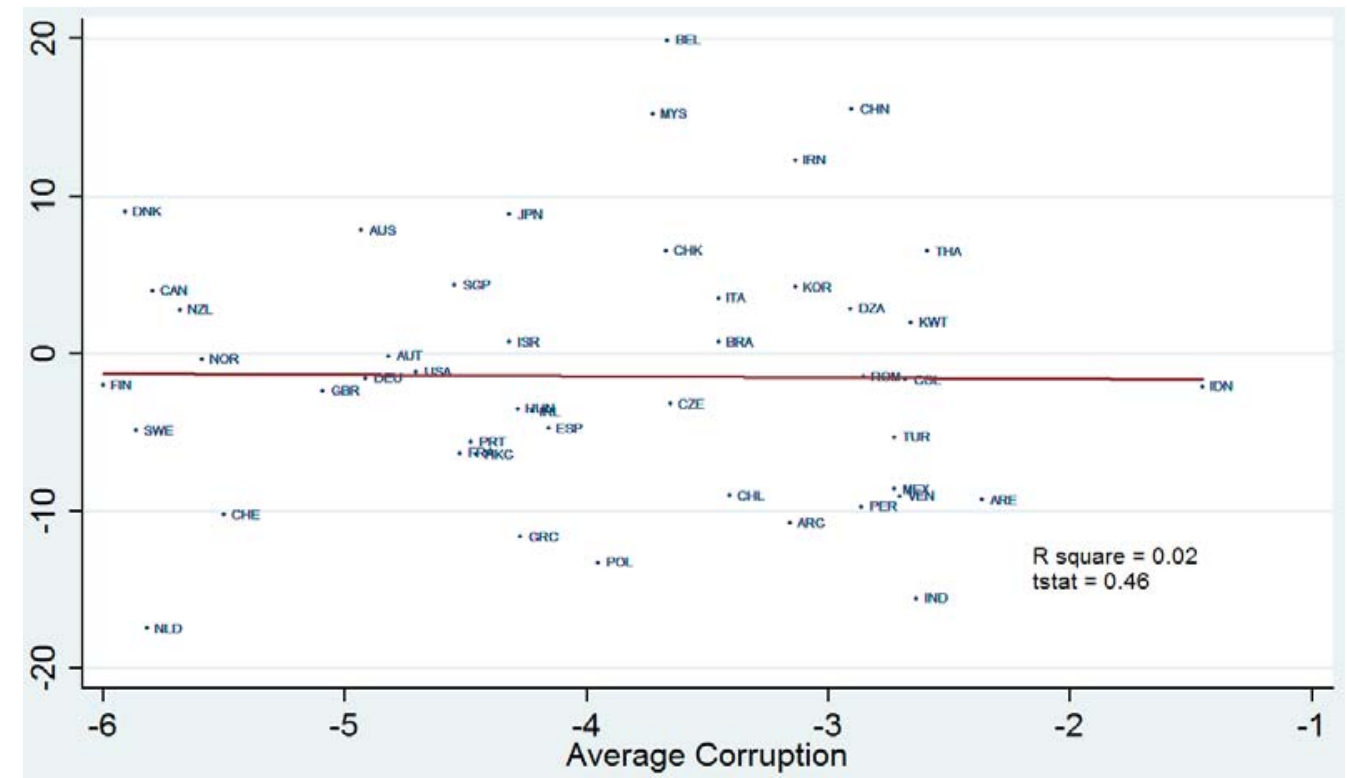

(a) Corruption

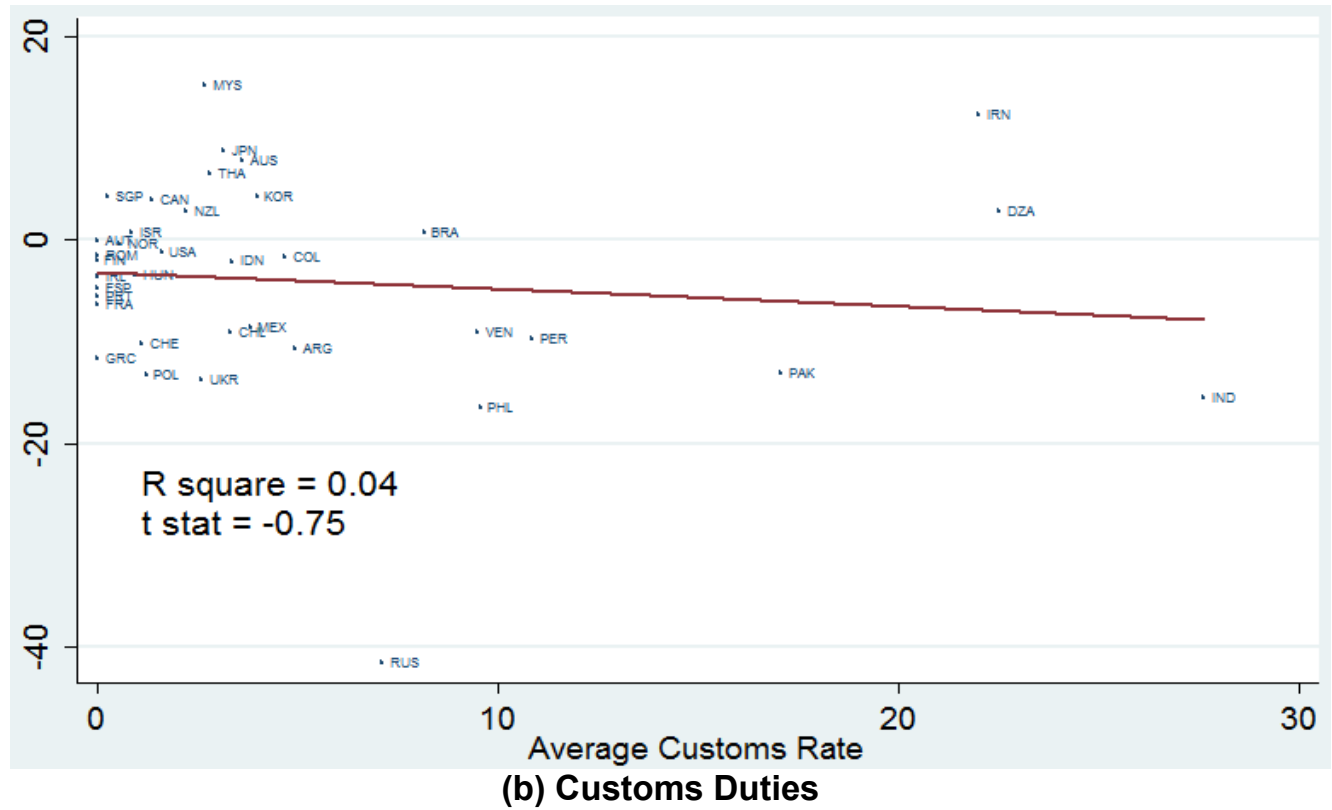




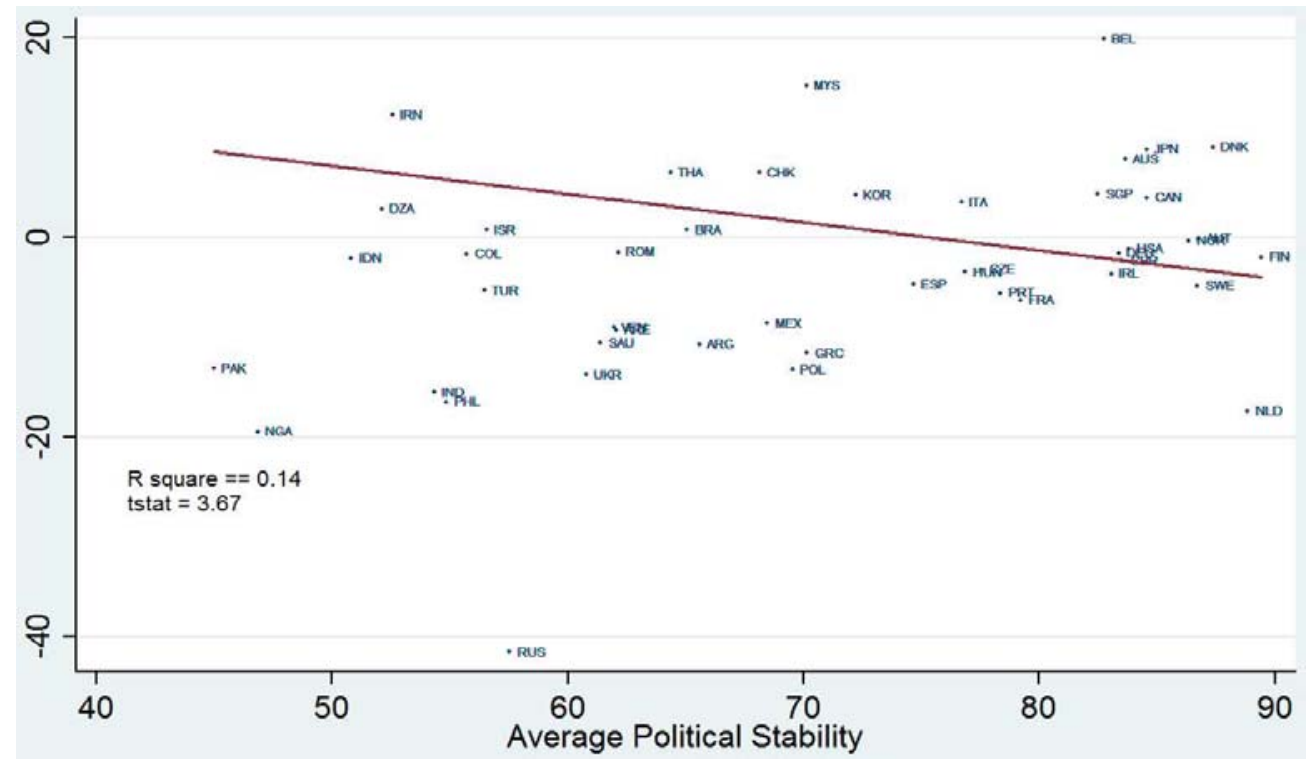

(c) Political Stability

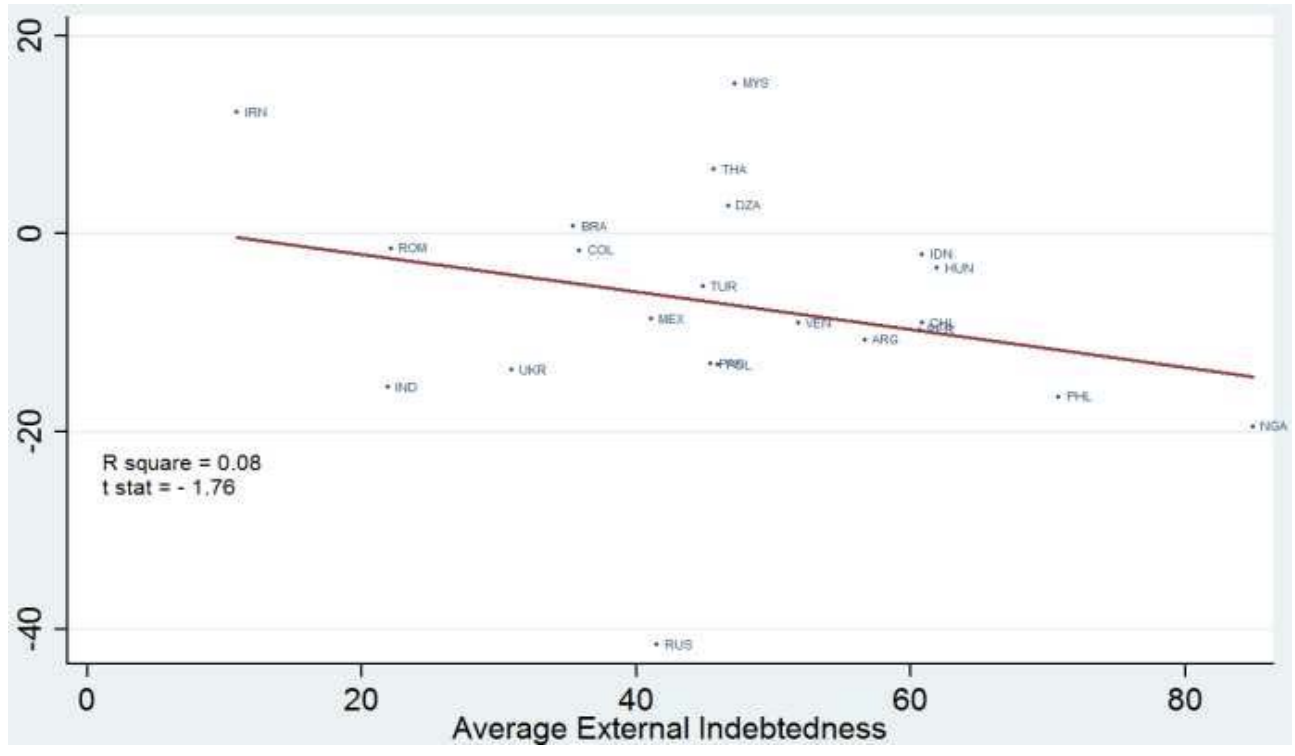

(d) Indebtedness 


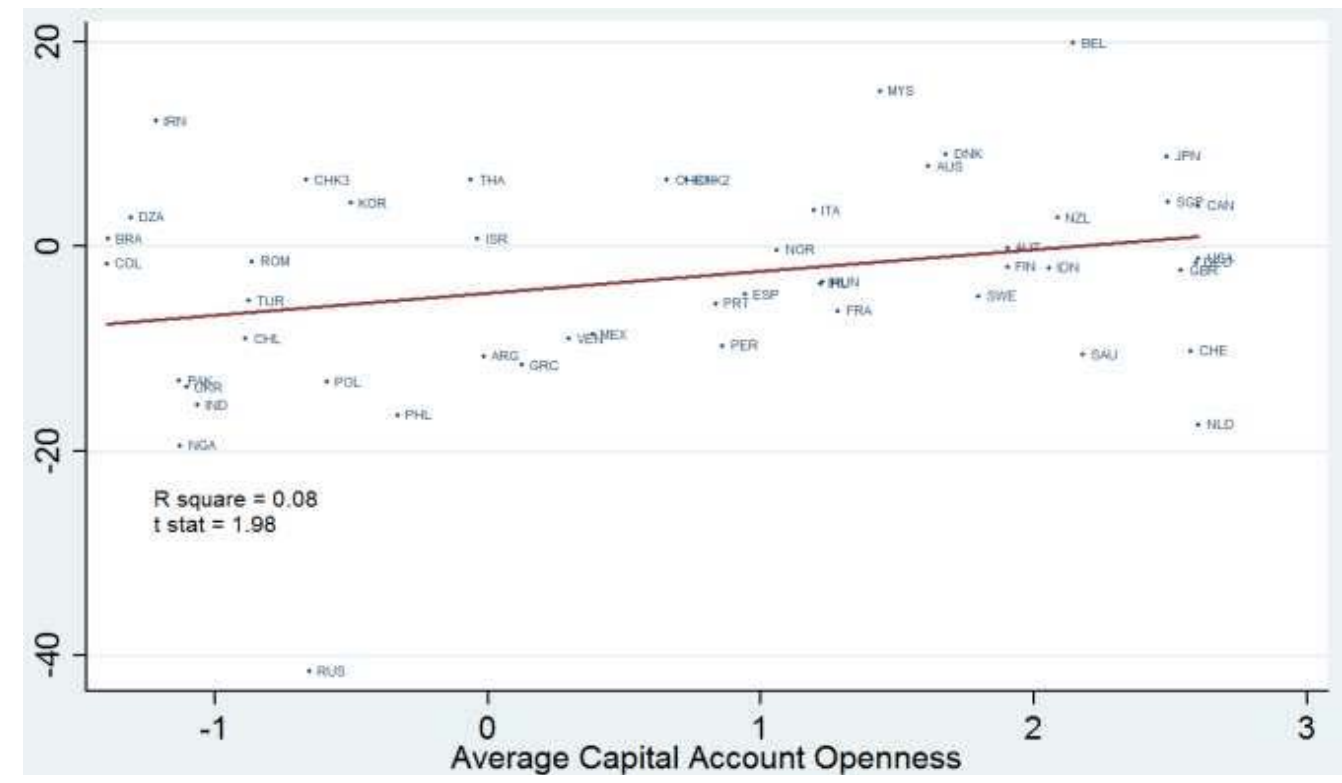

(e) Capital Account Openness

Political stability continues to be associated with capital flight in the expected direction. More stable countries witness lower import overinvoicing limiting the extent of capital flight. Finally, we obtain the rather surprising relationship between indebtedness and import overinvoicing. More indebted countries are found to engage in lower import overinvoicing. A closer look at the countries reveals that this result is largely driven by Philippines as well as Latin American economies like Argentina and Peru, which have witnessed high levels of external indebtedness but have experienced relatively modest capital flight through import misinvoicing.

\section{Regression Analysis}

In this section, we use regression analysis to study the principal determinants of cross-country variation in the level of trade misinvoicing over the period 1980 to 2005. Our primary dependent variable is trade misinvoicing measured as export underinvoicing as well as import overinvoicing vis-á-vis industrialized countries.

Apart from the variables introduced in Section 3, we also look at a number of other variables that can influence capital flightiii. Countries with high current account deficit are likely to experience capital moving off to foreign shores. A persistent current account deficit can be looked upon as a manifestation of economic instability and induces capital owners to transfer resources to foreign shores. A country that is faced with persistent current account deficit is likely to undertake a devaluation to improve the 
current account balance. Alternatively, it can raise resources internally by engineering a transfer from the private sector. This can happen either by direct appropriation/nationalization of private assets or generating seignorage revenue through an inflation tax. In either of the cases the private sector will have the incentive to move its assets beyond the control of the government.

Capital flight also tends to occur in countries, which have low political stability. Politically less stable countries such as Nigeria and Zimbabwe have experienced a substantial volume of capital flight through import misinvoicing. Political instability causes capital flight as agents seek to minimize the risk of expropriation and future portfolio losses due to political crisis.

Capital is likely to illegally move from home country to a foreign country if the returns are higher in the latter. To evaluate this possibility we look at both the real interest rate prevailing in the home country as well as the real interest rate spread. While the real interest rate is calculated by looking at the difference between the deposit rates prevailing in a country and the inflation rate, the real interest rate spread is the difference between real deposit rates in the home country and a risk free real interest rate. We proxy the risk free real interest rate with real deposit rates prevailing in the United States ${ }^{\text {iv }}$. One would expect capital flight to be inversely related with real deposit rates and positively related with real interest rate spread.

Tables 1 and 3 display the regression results employing feasible generalized least squares estimation. We allow for the presence of AR (1) autocorrelation within panels and a heteroscedastic error structure. While Table 1 illustrates the principal determinants of capital flight through export underinvoicing vis-a-vis industrialized countries, Table 3 highlights principal predictors of capital flight through overinvoicing of imports with industrialized countries. Looking across Tables 1 and 3 it is evident that while countries can engage in capital flight through both export underinvoicing and import overinvoicing, the underlying factors driving these are quite different. 
Table 1: FGLS Estimates: Determinants of Export Underinvoicing

Dependent Variable: Share of Export Underinvoicing in Exports to Industrialised Countries

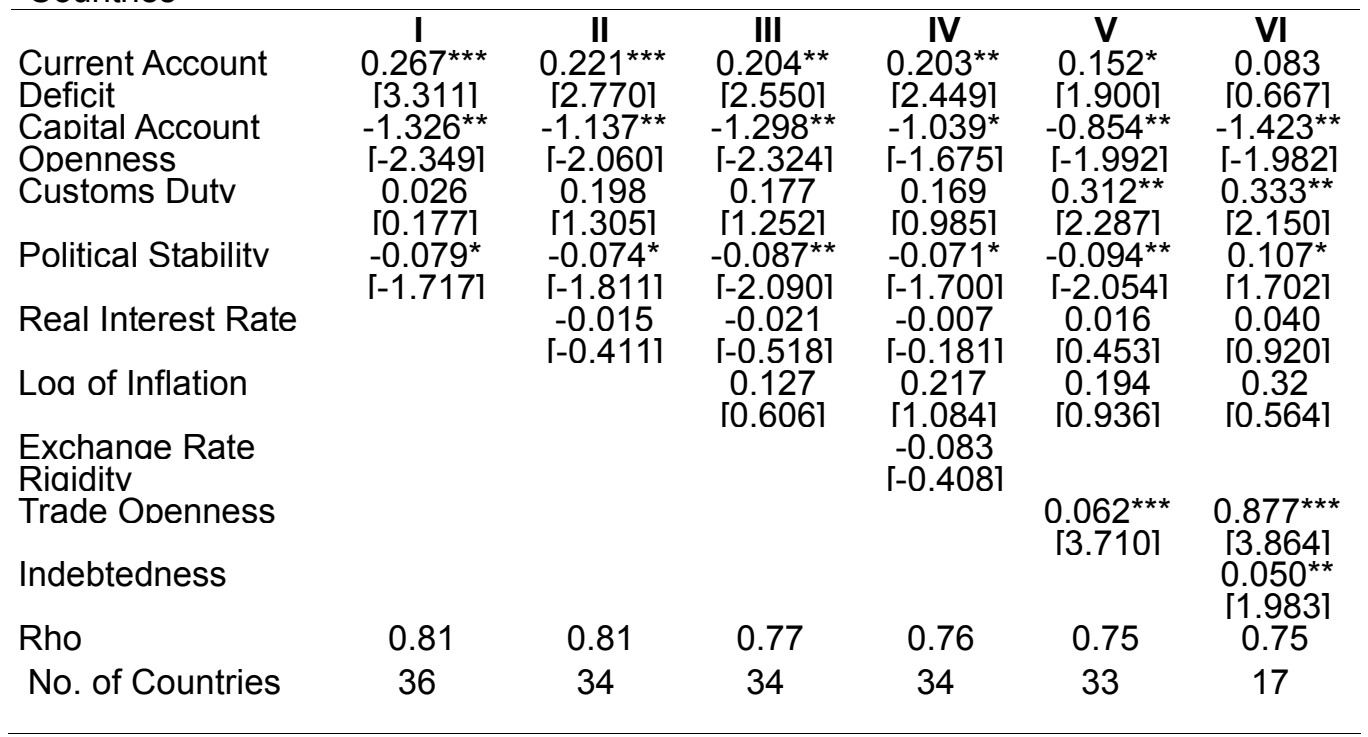

Robust $t$ statistics in parentheses.

*** indicates significance at $1 \%$

** indicates significance at $5 \%$

* indicates significance at $10 \%$

Columns I to VI indicate different sets of countries. Missing values in the columns reflect absence of data for those variables in that set of countries.

One of the key determinants of capital flight through export underinvoicing is the extent of current account deficit. This variable is significant across almost all the specifications outlined in Table 1. A one percentage point increase in the ratio of current account deficit to GDP raises capital flight through export underinvoicing by 0.15 to 0.26 percentage points. A higher current account deficit raises the probability of devaluation of the domestic currency, and reduces the incentive to invest in domestic assets. In such circumstances, investors seek out different routes to acquire foreign assets.

A rise in capital account openness is associated with a strong and significant decline in export overinvoicing. As countries undertake greater integration with the global financial market, allowing domestic residents to buy and sell foreign assets, the incentive to take out capital through trade misinvoicing diminishes. An increase in the capital account liberalization index by 0.1 points, by modifying laws to allow freer movement of capital, results in lowering export misinvoicing by 0.8 to 1.3 percentage points.

Apart from the above direct impact on capital flight, liberalization of the capital 
account can influence the extent of capital flight through what Kose et al. (2006) term as 'potential collateral benefits' of financial integration. Liberalization of the capital account can act as a catalyst for imposing discipline on macroeconomic policy. With financial globalization, the threat of capital outflow, in the face of opportunistic policies, acts as a 'disciplining effect' for the policymaker. Thus, an open capital account induces policymakers to undertake and adhere to good policies. As pointed out by Tytell and Wei (2004) these include national competition policy, regulation of banks, equity and labour markets and finally, monetary and fiscal policy. Several papers like Tytell and Wei (2004), Gruben and McLeod (2002) and Razin and Yuen (1995) have argued that capital account openness appears to lower inflation by disciplining monetary authorities. Similarly, Kim (2003) goes on to argue that capital account liberalization is associated with a lower fiscal deficit. Finally, countries with better institutions tend to have fewer restrictions on capital account transactions: capital account liberalisation is often correlated with improvements in institutional capacity in the country. For these reasons, there is a need for caution in interpreting the causal link between de jure capital account liberalisation and misinvoicing.

Adherence to good policies like low inflation and fiscal deficit increases the economic stability of the country and boosts the confidence of investors to hold assets within the country thereby reducing the extent of capital flight.

On the other hand, increased trade openness is associated with greater capital flight. Export misinvoicing increases by about 0.8 percentage points with an increase in trade openness of one percentage point. A larger tradeable sector offers greater opportunities for agents to misinvoice trade, with the objective of moving capital outside the country.

Political stability also shows up as a significant predictor of capital flight and has a strong negative influence on export underinvoicing. Typically, in countries with low political stability, residents take out their money to avoid the possibility that government in some form can erode the future value of such holdings. Higher customs duties are also associated with higher capital flight although the impact is not significant across all specifications. On the other hand, real interest rate, inflation rate and exchange rate regime do not have a significant impact on export underinvoicing.

Finally, we find that countries with higher external indebtedness have experienced greater capital flight. A number of reasons have been forwarded for the positive association between capital flight and external debt. Debt disbursements can signal an increase in the probability of a fiscal crisis and induce capital flight. Provision of external debt is also likely to put upward pressure on domestic currency, motivating residents to acquire foreign assets before an expected devaluation takes place. 


\begin{tabular}{|c|c|c|c|c|c|c|c|c|c|}
\hline \multicolumn{10}{|c|}{ Dependent Variable: Share of Export Underinvoicing in Exports to Industrialized Countries } \\
\hline & \multicolumn{5}{|c|}{ Industrialized Countries } & \multicolumn{4}{|c|}{ Developing Countries } \\
\hline & $\mathrm{I}$ & II & III & IV & v & VI & VII & VIII & IX \\
\hline $\begin{array}{l}\text { Current } \\
\text { Account } \\
\text { Deficit }\end{array}$ & $\begin{array}{c}-0.188 \\
{[-1.134]}\end{array}$ & $\begin{array}{c}0.042 \\
{[0.272]}\end{array}$ & $\begin{array}{c}0.018 \\
{[0.115]}\end{array}$ & $\begin{array}{c}-0.039 \\
{[-0.222]}\end{array}$ & $\begin{array}{c}-0.04 \\
{[-0.244]}\end{array}$ & $\begin{array}{c}0.322^{* * *} \\
{[3.414]}\end{array}$ & $\begin{array}{c}0.298^{\star \star * *} \\
{[3.216]}\end{array}$ & $\begin{array}{c}0.285^{\star \star \star *} \\
{[2.900]}\end{array}$ & $\begin{array}{l}0.260^{* *} \\
{[2.154]}\end{array}$ \\
\hline $\begin{array}{l}\text { Capital } \\
\text { Account } \\
\text { Openness }\end{array}$ & $\begin{array}{c}-0.183 \\
{[-0.0894]}\end{array}$ & $\begin{array}{c}0.645 \\
{[0.339]}\end{array}$ & $\begin{array}{c}0.24 \\
{[0.136]}\end{array}$ & $\begin{array}{c}0.07 \\
{[0.0366]}\end{array}$ & $\begin{array}{c}0.534 \\
{[0.300]}\end{array}$ & $\begin{array}{l}-1.006^{* *} \\
{[-2.475]}\end{array}$ & $\begin{array}{l}-1.196^{* *} \\
{[-1.969]}\end{array}$ & $\begin{array}{c}-1.249^{* *} \\
{[-1.982]}\end{array}$ & $\begin{array}{l}-1.407^{* *} \\
{[-2.074]}\end{array}$ \\
\hline $\begin{array}{l}\text { Customs } \\
\text { Duty }\end{array}$ & $\begin{array}{c}2.366^{\star \star *} \\
{[3.625]}\end{array}$ & $\begin{array}{l}2.122^{\star * \star} \\
{[3.596]}\end{array}$ & $\begin{array}{c}2.131^{* * *} \\
{[3.866]}\end{array}$ & $\begin{array}{c}2.061^{* * *} \\
{[3.472]}\end{array}$ & $\begin{array}{c}1.681^{* * *} \\
{[2.725]}\end{array}$ & {$\left[\begin{array}{c}-0.123 \\
{[-0.741]}\end{array}\right.$} & $\begin{array}{c}0.038 \\
{[0.220]}\end{array}$ & $\begin{array}{c}0.012 \\
{[0.0706]}\end{array}$ & $\begin{array}{c}0.084 \\
{[0.674]}\end{array}$ \\
\hline $\begin{array}{l}\text { Political } \\
\text { Stability }\end{array}$ & $\begin{array}{c}0.008 \\
{[0.0991]}\end{array}$ & $\begin{array}{c}0.075 \\
{[0.997]}\end{array}$ & $\begin{array}{c}0.068 \\
{[0.877]}\end{array}$ & $\begin{array}{c}0.079 \\
{[1.007]}\end{array}$ & $\begin{array}{c}0.108 \\
{[1.347]}\end{array}$ & $\begin{array}{l}-0.171^{* \star} \\
{[-2.519]}\end{array}$ & $\begin{array}{c}- \\
0.193^{\star * *} \\
{[-3.016]}\end{array}$ & $\begin{array}{c}-0.193^{\star \star *} \\
{[-2.896]}\end{array}$ & $\begin{array}{c}-0.216^{\star * \star} \\
{[-3.019]}\end{array}$ \\
\hline $\begin{array}{l}\text { Real Interest } \\
\text { Rate }\end{array}$ & & $\begin{array}{c}-0.432^{* * *} \\
{[-2.802]}\end{array}$ & $\begin{array}{c}-0.383^{* *} \\
{[-2.113]}\end{array}$ & $\begin{array}{c}-0.405^{* *} \\
{[-2.066]}\end{array}$ & $\begin{array}{c}-0.382^{* *} \\
{[-2.179]}\end{array}$ & & $\begin{array}{c}-0.004 \\
{[-} \\
0.0948]\end{array}$ & $\begin{array}{c}0.001 \\
{[0.0261]}\end{array}$ & $\begin{array}{c}-0.039 \\
{[-0.824]}\end{array}$ \\
\hline $\begin{array}{l}\text { Log of } \\
\text { Inflation }\end{array}$ & & & $\begin{array}{c}-0.137 \\
{[-0.270]}\end{array}$ & $\begin{array}{c}-0.125 \\
{[-0.241]}\end{array}$ & $\begin{array}{c}-0.108 \\
{[-0.212]}\end{array}$ & & & $\begin{array}{c}0.361 \\
{[1.398]}\end{array}$ & $\begin{array}{c}-0.011 \\
{[-0.0265]}\end{array}$ \\
\hline $\begin{array}{l}\text { Exchange } \\
\text { Rate Rigidity }\end{array}$ & & & & $\begin{array}{c}-0.191 \\
{[-0.714]}\end{array}$ & & & & & $\begin{array}{c}-0.324 \\
{[-0.763]}\end{array}$ \\
\hline $\begin{array}{l}\text { Trade } \\
\text { Openness }\end{array}$ & & & & & $\begin{array}{c}-0.059 \\
{[-1.642]}\end{array}$ & & & & \\
\hline \multicolumn{10}{|l|}{ Indebtedness } \\
\hline rho & 0.73 & 0.74 & 0.69 & 0.72 & 0.68 & 0.85 & 0.83 & 0.81 & 0.61 \\
\hline $\begin{array}{l}\text { Number of } \\
\text { Countries }\end{array}$ & 11 & 11 & 11 & 11 & 11 & 25 & 23 & 23 & 23 \\
\hline
\end{tabular}

Robust t statistics in parentheses.

*** indicates significance at $1 \%,{ }^{* *}$ indicates significance at $5 \%$ and ${ }^{*}$ indicates significance at $10 \%$.

Columns I to IX indicate different sets of countries. Missing values in the columns reflect absence of data for those variables in that set of countries.

Focusing on subsamples and looking specifically at the industrialized and developing countries separately one can see that the overall results are largely driven by the performance of the developing countries. For the industrialized countries, customs duty and real interest rate show up as key predictors of export misinvoicing. The positive relationship between customs duty and export underinvoicing is largely driven by countries like Australia and Japan, which maintained relatively high customs duties. On the other hand, in developing countries, export underinvoicing can largely be explained by capital account openness, political stability and trade openness. Countries like Singapore, Czech Republic, Ireland and Peru had undertaken significant liberalization of the capital account over the last two decades and witnessed diminishing capital flight through export misinvoicing during this period. Countries like India, Philippines and Columbia, however, which moved relatively little on liberalization of capital account 
during most of this period, witnessed strong capital flight through trade misinvoicing. More politically stable countries like Singapore, Czech Republic and Korea witnessed lower misinvoicing compared to countries like Pakistan, Nigeria and Algeria. Finally, trade openness also shows up as a significant predictor of trade misinvoicing among developing countries.

Next, when we focus on the key determinants of capital flight through import overinvoicing, the results are quite different from above. The current account deficit continues to be a significant determinant of capital flight through import overinvoicing. Again, across all specifications it exerts a significant positive impact on trade misinvoicing. However, both capital account openness and political stability do not have a significant impact on trade misinvoicing. Customs duties now show up as a strong determinant of import overinvoicing. Higher custom duties exert a strong negative impact on the desire to overinvoice and the effect is significant across all specifications. By reporting a lower value of shipment, traders are able to evade import tariffs or custom duties, avoid quotas, and launder illegally obtained money, and engage in capital flight. We find that a one percentage point increase in custom duties reduces import overinvoicing by around 0.3 percentage points.

\begin{tabular}{|c|c|c|c|c|c|c|}
\hline \multicolumn{7}{|c|}{ Dependent Variable: Share of Import Overinvoicing in Imports to Industrialised Countries } \\
\hline & I & II & III & IV & $\mathrm{V}$ & $\mathrm{VI}$ \\
\hline Current Account & $0.260^{\star \star \star}$ & $0.219^{* * *}$ & $0.232^{* * *}$ & $0.228^{* * *}$ & $0.246^{* * *}$ & $0.734^{* * *}$ \\
\hline Deficit & {$[4.846]$} & {$[3.208]$} & [3.331] & [2.906] & [3.205] & [2.619] \\
\hline Custom Duties & $\begin{array}{c}-0.357^{\star \star \star \star} \\
{[-3.448]}\end{array}$ & $\begin{array}{c}-0.332^{* * *} \\
{[-3.054]}\end{array}$ & $\begin{array}{c}-0.320^{* \star *} \\
{[-2.875]}\end{array}$ & $\begin{array}{l}-0.274^{\star *} \\
{[-2.396]}\end{array}$ & $\begin{array}{l}-0.275^{\star *} \\
{[-2.390]}\end{array}$ & $\begin{array}{l}-0.319^{* *} \\
{[-1.982]}\end{array}$ \\
\hline Overvaluation & $\begin{array}{c}0.028^{*} \\
{[1.935]}\end{array}$ & $\begin{array}{c}0.047^{* * *} \\
{[2.702]}\end{array}$ & $\begin{array}{l}0.053^{* * *} \\
{[2.994]}\end{array}$ & $\begin{array}{l}0.067^{* * *} \\
{[3.314]}\end{array}$ & $\begin{array}{l}0.073^{* * *} \\
{[3.574]}\end{array}$ & $\begin{array}{c}0.049 \\
{[1.295]}\end{array}$ \\
\hline Political Stability & $\begin{array}{c}-0.043 \\
{[-1.309]}\end{array}$ & $\begin{array}{c}-0.044 \\
{[-1.038]}\end{array}$ & $\begin{array}{c}-0.042 \\
{[-1.018]}\end{array}$ & $\begin{array}{c}-0.022 \\
{[-0.375]}\end{array}$ & $\begin{array}{c}-0.028 \\
{[-0.462]}\end{array}$ & $\begin{array}{c}-0.113 \\
{[-0.746]}\end{array}$ \\
\hline Capital Account & & -0.188 & -0.35 & -0.664 & -0.84 & 1.003 \\
\hline Openness & & {$[-0.361]$} & {$[-0.592]$} & {$[-0.982]$} & {$[-1.218]$} & [0.830] \\
\hline Log of Inflation & & & & $\begin{array}{c}-0.469 \\
{[-1.009]}\end{array}$ & $\begin{array}{c}-0.464 \\
{[-0.986]}\end{array}$ & $\begin{array}{c}-2.781 \\
{[-1.567]}\end{array}$ \\
\hline Real Rate & $\begin{array}{c}0.071^{* * *} \\
{[3.434]}\end{array}$ & $\begin{array}{c}0.053 \\
{[1.568]}\end{array}$ & & $\begin{array}{c}0.046 \\
{[1.184]}\end{array}$ & & $\begin{array}{c}-0.005 \\
{[-0.0646]}\end{array}$ \\
\hline \multirow{3}{*}{$\begin{array}{l}\text { Exchange Rate } \\
\text { Regime } \\
\text { Real Interest Rate } \\
\text { Differential } \\
\text { Indebtedness }\end{array}$} & & & & $\begin{array}{c}-0.586 \\
{[-1.555]}\end{array}$ & $\begin{array}{c}-0.571 \\
{[-1.494]}\end{array}$ & $\begin{array}{c}1.32 \\
{[1.324]}\end{array}$ \\
\hline & & & -0.042 & & -0.023 & \\
\hline & & & {$[-1.160]$} & & {$[-0.475]$} & $\begin{array}{c}-0.026 \\
{[-0.357]}\end{array}$ \\
\hline rho & 0.79 & 0.79 & 0.80 & 0.72 & 0.74 & 0.74 \\
\hline Number of Countries & 33 & 33 & 33 & 33 & 33 & 16 \\
\hline \multicolumn{7}{|c|}{$\begin{array}{l}\text { Robust t statistics in parentheses. } \\
* * * \text { indicates significance at } 1 \%,{ }^{* *} \text { indicates significance at } 5 \% \text { and }{ }^{*} \text { indicates significance at } \\
10 \% \text {. } \\
\text { Columns I to VI indicate different sets of countries. Missing values in the columns reflect } \\
\text { absence of data for those variables in that set of countries. }\end{array}$} \\
\hline
\end{tabular}


Another important variable explaining the extent of misinvoicing is the extent of currency overvaluation. Exchange rate overvaluation induces devaluation expectations, which could induce capital flight for hedging purposes. The farther the adjustment is postponed, the stronger the expectation will be for the devaluation. Moreover, in some Latin American countries like Argentina and Mexico, the central bank and the government authorized transfers abroad at the official exchange rates. In such instances, capital flight was a direct result of overvaluation. We find that a one percentage point increase in overvaluation results in 0.03 to 0.07 percentage point increase in capital flight through import overinvoicing. The real interest rate has a sign opposite to may be expected. However, once we control for other variables like capital account openness, exchange rate regime, etc. we obtain the expected sign but the impact is not significant across any of the specifications. Similarly, the real interest rate differential, the exchange rate regime, indebtedness and inflation do not have a significant impact on import overinvoicing.

Splitting the overall sample into developing and industrialized countries yields a similar result as before with bulk of the results being driven by the developing countries.

\section{v. Key Results}

With the help of a combination of graphical and econometric analysis we arrive at the following key results:

- The extent of misinvoicing is seen to be higher among developing countries than industrialized countries over the period 1980-2005. Also, misinvoicing has declined steadily in industrialized countries, while with developing countries, trends remain mixed.

- Though there is evidence of misinvoicing in countries all over the world, our regression results suggest that different factors are at play in affecting export underinvoicing and import overinvoicing.

- Current account deficit, custom duties and currency overvaluation are the main factors that impact import overinvoicing.

- Export underinvoicing is found to be affected by political instability, capital account openness, current account deficit, trade openness and external indebtedness.

- We also find that there are different factors affecting export misinvoicing in developing and industrialized countries. While current account deficit, capital account openness and political instability are the primary factors driving export underinvoicing in developing countries, custom duties and interest rates are the significant variables driving export underinvoicing in industrialized countries.

\section{Conclusion and Further Research}

Economists have long been aware of trade misinvoicing. The traditional literature has focused on evasion of custom duties and economic instability, as being the 
forces at work with misinvoicing. If misinvoicing was driven by economic instability and custom duties, in many emerging markets such as China and India, conditions had changed enough to deliver a sharp reduction in misinvoicing. The broad summary statistics suggest that such a reduction has not taken place. This suggests the need for a further exploration of the factors affecting misinvoicing.

In this paper we examine the evidence in both industrial and emerging economies. We find that while there are many macroeconomic and institutional variables affecting misinvoicing, they vary in industrial and emerging economies. Moreover, the variables that affect export misinvoicing are different from those affecting import misinvoicing. The paper highlights that custom duties and economic instability are not the only factors leading to capital flight through trade misinvoicing, as previously believed. Capital account openness, interest rate differentials and the exchange rate regime play an important role.

There is a need for further research to understand why different institutional mechanisms are affecting misinvoicing in developing and industrial countries. Moreover, when custom duties have been drastically reduced in developing countries post liberalization, why do they continue to play a vital role even today in import misinvoicing? We find that capital account openness plays a major role in export misinvoicing. However, we do not get a similar relationship in the case of import overinvoicing. In the latter case, we believe that the net import misinvoicing is a result of two competing factors - desire to keep capital out of the country leading to import overinvoicing, and the willingness to evade custom duties resulting in import underinvoicing. The importance of each factor is an area for further research. 


\section{References}

Aizenman J. 2003. On the Hidden Links Between Financial and Trade Opening. NBER Working Paper No. 9906.

Aizenman J. 2004. "Financial Opening and Development: Evidence and Policy Controversies". American Economic Review, 94 (2); 65-70.

Aizenman J. and I. Noy, 2004. On the Two Way Feedback between Financial and Trade Openness. NBER Working Paper No. 10496.

Aizenman J. and I. Noy, 2008. "Endogenous Financial and Trade Openness". Review of International Economics (forthcoming).

Beja E., P. Junvith, and J. Ragusett, 2005. "Capital Flight from Thailand, 19802000", in (ed.) G. Epstein, Capital Flight and Capital Controls in Developing Countries, chapter 6; 143-172. Edward Elgar Publishing.

Boyce J. K. 2002. "The Revolving Door? External Debt and Capital Flight: A Philippine Case Study". World Development, 20 (3); 335-49.

Boyce J. K. and L. Ndikumana, 2001. "Is Africa a Net Creditor? New Estimates of Capital Flight from Severely Indebted Sub-Saharan African Countries, 19701996". Journal of Development Studies, 38 (2); 27-56.

Chinn M. D. and H. Ito 2006. "What Matters for Financial Development? Capital Controls, Institutions and Interactions". Journal of Development Economics, 81 (1); 163192.

Cuddington J. T., 1986. "Capital Flight, Issues and Explanations". Princeton Studies in International Finance, 58. Princeton: New Jersey.

Cuddington J. T. 1987. "Macroeconomic Determinants of Capital Flight: An Econometric Investigation" in (eds.) D. R. Lessard and J. Williamson, Capital Flight and Third World Debt, Institute of International Economics, Washington DC.

de Boyrie M., J. Nelson and S. Pak, 2007. "Capital Movement Through Trade Misinvoicing: The Case of Africa". Journal of Financial Crime, 14 (4); 474-489.

Gruben, W. C. and D. McLeod, 2002. "Capital Account Liberalization and Inflation". Economic Letters, 77 (2); 221-225.

Hermes N. and R. Lensink, 1992. "The Magnitude and Determinants of Capital Flight: The Case for Six Sub-Saharan African Countries'. De Economist, 140 (4); 515-30.

Johnson, S., J. D. Ostry, and A. Subramanian, 2007. "The Prospects for Sustained Growth in Africa: Benchmarking the Constraints". IMF Working Paper, WP/07/52. 
Ketkar S. L. and K. W. Ketkar, 1989. "Determinants of Capital Flight from Argentina, Brazil, and Mexico". Contemporary Policy Issues, 7 (3); 1-29.

Khan M. S. and N. UI-Haque, 1985. Foreign Borrowing and Capital Flight: A Formal Analysis. IMF Staff Papers, 32.

Kim W. 2003. "Does Capital Account Liberalization Discipline Budget?" Review of International Ecoomics, 11 (5); 830-844.

Kose M. A., E. Prasad, K. Rogoff, and S.-J. Wei, 2006. "Financial Globalization: A Reappraisa". NBER Working Paper, 12484.

Levy-Yeyati E. and F. Sturzenegger, 2005. "Classifying Exchange Rate Regimes: Deeds vs. Words". European Economic Review, 49 (6); 1603-1635.

Murinde V., N. Hermes, and R. Lensink, 1996. "Comparative Aspects of the Magnitude and Determinants of Capital Flight in Six Sub-Saharan African Countries". Savings and Development Quarterly Review, 20 (1); 61-78.

Muscatelli A. and A. H. Hallett, 1992. "How Successfully Do We Measure Capital Flight? Evidence from Five Developing Countries". Journal of Development Studies, 28 (3); 538-556.

Ndikumana L. and J. K. Boyce, 2002. "Public Debts and Private Assets: Explaining Capital Flight from Sub-Saharan African Countries". World Development, 31 (1); 107130.

Ngeno N. K. 2000. "Capital Flight in Kenya" in (eds.) I. Ajayi and M. S. Khan, External Debt and Capital Flight in Sub-Saharan Africa, ;300-21. The IMF Institute, Washington DC.

Pastor M., 1990. "Capital Flight from Latin America”. World Development, 18 (1); 1-18.

Razin A. and C.-W. Yuen, 1995. "Can Capital Controls Alter the Inflation-Unemployment Tradeoff?” NBER Working Paper 5239.

Schulze G. 1994. "Misinvoicing Imports: the Interdependence of Tax and Tariff Evasion”. Public Finance Review, 22 (3); 335-365.

Tytell I. and S. J. Wei, 2004. "Does Financial Globalization Induce Better Macroeconomic Policies?” IMF Working Paper No. 04/84.

Vos R. 1992. "Private Foreign Asset Accumulation, Not Just Capital Flight: Evidence from the Philippines". Journal of Development Studies, 28 (3); 500-37.

Vu Le Q. and Zak P. 2001. Political Risk and Capital Flight. Claremont Colleges Working Paper 2001-10.

Wei S. and Z. Zhang, 2007. "Collateral Damage: Exchange Controls and International 
Trade". Journal of International Money and Finance, 26 (5); 841-863. 


\section{Appendix}

\section{A List of Countries}

\begin{tabular}{|l|l|l|}
\hline \multicolumn{1}{|c|}{ Industrialized Countries } & \multicolumn{2}{c|}{ Developing Countries } \\
\hline Australia & Algeria & Mexico \\
\hline Austria & Argentina & Nigeria \\
\hline Belgium & Brazil & Pakistan \\
\hline Canada & Chile & Peru \\
\hline Denmark & CHK & Philippines \\
\hline Finland & Colombia & Poland \\
\hline France & Egypt & Portugal \\
\hline Germany & Greece & Romania \\
\hline Italy & Hungary & Russia \\
\hline Japan & India & Saudi Arabia \\
\hline Netherlands & Indonesia & Singapore \\
\hline New Zealand & Iran, I. R. of & South Africa \\
\hline Norway & Ireland & Thailand \\
\hline Spain & Israel & Turkey \\
\hline Sweden & Korea & Ukraine \\
\hline Switzerland & Kuwait & United Arab Emirates \\
\hline United Kingdom & Malaysia & Venezuela, Rep. Bol. \\
\hline United States & & \\
\hline
\end{tabular}

\section{B Data Sources and Definitions}

\begin{tabular}{|l|l|l|}
\hline Variable & Source & Definition \\
\hline Trade openness & $\begin{array}{l}\text { World Development } \\
\text { Indicators }\end{array}$ & $\begin{array}{l}\text { Sum of exports and imports of goods and services } \\
\text { in GDP. }\end{array}$ \\
\hline $\begin{array}{l}\text { External } \\
\text { indebtedness }\end{array}$ & $\begin{array}{l}\text { World Development } \\
\text { Indicators }\end{array}$ & $\begin{array}{l}\text { Debt owed to non-residents repayable in foreign } \\
\text { currency, goods or services. Includes public, } \\
\text { publicly guaranteed long-term debt, IMF credit, } \\
\text { short-term debt. }\end{array}$ \\
\hline $\begin{array}{l}\text { Average custom } \\
\text { duties }\end{array}$ & $\begin{array}{l}\text { World Development } \\
\text { Indicators }\end{array}$ & $\begin{array}{l}\text { Ratio of total customs revenue on merchandise } \\
\text { goods to value of merchandise goods imported into } \\
\text { the country. }\end{array}$ \\
\hline Political stability & $\begin{array}{l}\text { Intra Country Risk } \\
\text { Guide }\end{array}$ & $\begin{array}{l}\text { A weighted index of 12 components including } \\
\text { government stability, socio-economic conditions, } \\
\text { investment profile, conflicts, corruption, law and } \\
\text { order and ethnic tensions. Index ranges from 0 to } \\
100 ; \text { a higher score reflecting a more stable } \\
\text { regime. }\end{array}$ \\
\hline
\end{tabular}




\begin{tabular}{|c|c|c|}
\hline Corruption & $\begin{array}{l}\text { Intra Country Risk } \\
\text { Guide }\end{array}$ & $\begin{array}{l}\text { The corruption index ranges from } 0 \text { to } 6 \text {, a higher } \\
\text { number indicating a less corrupt regime. In the } \\
\text { paper we take an inverse of this measure. A higher } \\
\text { number hence refers to greater corruption. }\end{array}$ \\
\hline Inflation & $\begin{array}{l}\text { World Development } \\
\text { Indicators }\end{array}$ & Annual growth rate of GDP implicit deflator. \\
\hline $\begin{array}{l}\text { GDP implicit } \\
\text { deflator }\end{array}$ & $\begin{array}{l}\text { World Development } \\
\text { Indicators }\end{array}$ & $\begin{array}{l}\text { Ratio of GDP in current local currency to GDP in } \\
\text { constant local currency. }\end{array}$ \\
\hline Real interest rate & $\begin{array}{l}\text { World Development } \\
\text { Indicators }\end{array}$ & $\begin{array}{l}\text { Difference between nominal deposit rate and } \\
\text { inflation rate. }\end{array}$ \\
\hline $\begin{array}{l}\text { Real interest rate } \\
\text { differential }\end{array}$ & $\begin{array}{l}\text { World Development } \\
\text { Indicators }\end{array}$ & $\begin{array}{l}\text { Difference between real deposit rates in the home } \\
\text { country and a risk free real interest rate. Risk free } \\
\text { real interest rate is proxied with real deposit rates } \\
\text { prevailing in the United States. A positive real } \\
\text { interest rate differential implies that the risk free } \\
\text { real interest rate is higher than real interest rates } \\
\text { prevailing in the home country. }\end{array}$ \\
\hline $\begin{array}{l}\text { Current account } \\
\text { balance }\end{array}$ & $\begin{array}{l}\text { World Development } \\
\text { Indicators }\end{array}$ & $\begin{array}{l}\text { Sum of net exports of goods, services, net income } \\
\text { and net current transfers. }\end{array}$ \\
\hline $\begin{array}{l}\text { Current account } \\
\text { deficit }\end{array}$ & $\begin{array}{l}\text { World Development } \\
\text { Indicators }\end{array}$ & $\begin{array}{l}\text { Ratio of GDP to current account balance. A } \\
\text { positive number indicates a current account deficit. }\end{array}$ \\
\hline $\begin{array}{l}\text { Exchange rate } \\
\text { regime }\end{array}$ & $\begin{array}{l}\text { Levy-Yeyati and } \\
\text { Sturzenegger (2005) }\end{array}$ & $\begin{array}{l}\text { A de facto classification of exchange rate index } \\
\text { formulated by Levy-Yeyati and Sturzenegger } \\
\text { based on data on exchange rates. The index } \\
\text { ranges from } 1 \text { to } 5 \text {, a lower number implying a } \\
\text { more flexible exchange rate regime. }\end{array}$ \\
\hline $\begin{array}{l}\text { Currency } \\
\text { overvaluation }\end{array}$ & Johnson et al (2007) & As defined in the source. \\
\hline $\begin{array}{l}\text { Capital account } \\
\text { openness }\end{array}$ & Chinn and Ito (2006) & $\begin{array}{l}\text { The Chinn-Ito index ranges from }-2.54 \text { to } 2.54 \text {, a } \\
\text { higher value indicating greater financial } \\
\text { openness. The index is } \\
\text { the first principal component of the binary } \\
\text { variables pertaining to cross border financial } \\
\text { transactions based on } \\
\text { IMF's categorical enumeration reported in the } \\
\text { Annual Report on Exchange Arrangements and } \\
\text { Exchange Restrictions. The variables are } \\
\text { restrictions on capital account transaction, } \\
\text { current account transaction, requiring } \\
\text { surrendering of export proceeds and presence of } \\
\text { multiple exchange rates. Since these variables } \\
\text { account for the degree of control, Chinn and Ito } \\
\text { flip their values and construct an index based on } \\
\text { standardized principal components. }\end{array}$ \\
\hline
\end{tabular}




\section{Summary Statistics of Key Variables}

\begin{tabular}{lccccc}
\hline Variable & Obs. & Mean & Std. Dev. & Min. & Max. \\
\hline Export Misinvoicing vis-à-vis IC & 1345 & 3.19 & 22.7 & -89.27 & 169.54 \\
Import Misinvoicing vis-à-vis IC & 1345 & -3.77 & 15.89 & -138.43 & 81.65 \\
Net Misinvoicing vis-à-vis IC & 1345 & -0.92 & 10.69 & -48.36 & 62.76 \\
Export Misinvoicing vis-à-vis & 1319 & -1.14 & 17.98 & -78.94 & 106.03 \\
Import Misinvoicing vis-à-vis & 1319 & -1.45 & 15.15 & -115.64 & 72.87 \\
Net Misinvoicing vis-à-vis World & 1319 & -1.41 & 8.74 & -43.56 & 31.28 \\
Political Stability & 1132 & 70.35 & 14.82 & 20.00 & 97.00 \\
Corruption & 1135 & 3.76 & 1.45 & 0.00 & 6.0 \\
Exchange Rate Rigidity & 1142 & 3.57 & 1.38 & 1.00 & 5.0 \\
Average Custom Duties & 652 & 6.42 & 9.09 & -0.09 & 66.34 \\
Inflation & 1329 & 40.96 & 282.99 & -25.70 & 6836.88 \\
Real Interest Rate & 1028 & 5.94 & 10.99 & -91.72 & 88.11 \\
Indebtedness & 616 & 45.05 & 25.72 & 0.74 & 158.57 \\
Capital Account Openness & 1263 & 0.81 & 1.64 & -1.77 & 2.5 \\
Real Interest Differential & 1028 & -0.47 & 11.02 & -80.12 & 95.34 \\
Trade Share & 1297 & 69.65 & 49.62 & 11.55 & 456.09 \\
Current Account Deficit & 1254 & 0.07 & 9.58 & -54.67 & 240.50 \\
Exchange Rate Overvaluation & 1251 & 6.93 & 40. & -231.79 & 193.03 \\
\hline
\end{tabular}


i The list of countries is given in Appendix A.

ii The definitions and data source of the variables used are given in Appendix B.

iii The variables used, their source and definitions are given in Appendix B.

iv A positive real interest rate spread implies that the real deposit rates in the United States are higher than in the home country. 
